\title{
A construção da cooperação sul-americana em segurança e defesa: o caso do Conselho de Defesa Sul-Americano
}

\author{
The construction of South American cooperation in security \\ and defense: the South American Defense Council
}

\section{La construcción de la cooperación suramericana en seguridad y defensa: el caso del Consejo de Defensa Suramericano}

\author{
Lisa Belmiro Camara \\ Doutoranda em Relações Internacionais pela Universidade Federal de Santa \\ Catarina (UFSC), Florianópolis (SC), Brasil. \\ E-mail: lisacamara@outlook.com \\ ORCID: https://orcid.org/0000-0001-9137-3643
}

Tomaz Espósito Neto

Professor da Faculdade de Direito e Relações Internacionais, Universidade Federal da Grande Dourados (UFGD), Dourados (MS), Brasil

E-mail: tomazneto@ufgd.edu.br ORCID: https://orcid.org/0000-0002-6139-8791

Resumo: Inserido na discussão da segurança regional, o objetivo central deste artigo é analisar a construção de um componente de segurança e defesa na América do Sul, ao verificar se o Conselho de Defesa Sul-Americano (CDS) pode ser entendido como parte do processo de concepção de uma identidade sul-americana, e como sua agenda e estrutura se adequam ou não às necessidades da região. A cooperação regional, enquanto um processo que tende a aproximar Estados por meio da convergência de interesses, abriga uma ampla variedade de temas, dentre os quais estão a segurança e a defesa. Neste sentido, o CDS representa a primeira iniciativa de cooperação em segurança e defesa entre todos os países da América do Sul. Por esta razão, a análise está situada na interseção dos níveis regional e doméstico, o que não exclui a interação com o nível internacional, cuja compreensão é necessária para se pensar as dinâmicas regionais. A amplitude teórica dos Complexos Regionais de Segurança é utilizada como lente para a reflexão, já que, segundo esta proposição, os problemas de segurança enfrentados pelos Estados de determinada região não podem ser pensados de forma separada, o que abre espaço para a possibilidade de se pensar esses assuntos de maneira conjunta, via instituições.

Palavras-chave:Segurança regional; América do Sul; Complexos Regionais de Segurança 
Abstract: Inserted in the discussion of regional security, the main objective of this article is analyze to analyze the construction of a security and defense component in South America, by verifying whether the South American Defense Council can be understood as part of the design process of a South American identity, and how its agenda and structure fit or not in the region needs. Regional cooperation, as a process that tends to bring States closer by means of convergence of interests, encompasses a wide variety of themes, among which are security and defense. In this sense, it represents the first security and defense cooperation initiative among all South American countries. For this reason, the analysis is located at the intersection of the regional and domestic levels, not excluding the interaction with the international level, whose understanding is necessary to think about regional dynamics. The theoretical breadth of the Regional Security Complexes is used as a lens for reflection, since, according to this proposition, the security problems faced by States in a given region cannot be thought of separately, which opens space for the possibility of thinking these issues jointly, via institutions.

Keywords: Regional security; South America; Regional Security Complex.

Resumen: En el marco de la discusión sobre seguridad regional, el objetivo principal de este artículo es analizar la construcción de un elemento de seguridad y defensa en América del Sur, verificando si el Consejo de Defensa Suramericano (CDS) puede ser entendido como parte del proceso de concepción de una identidad suramericana, y como su agenda y estructura se ajustan, o no, a las necesidades de la región. La cooperación regional, como proceso que tiende a acercar Estados por medio de la convergencia de intereses, engloba una amplia variedad de temas, entre los que se encuentran la seguridad y defensa. En ese marco, el CDS representa la primera iniciativa de cooperación en seguridad y defensa entre todos los países de América del Sur. Por esta razón, el análisis se sitúa en la intersección de los niveles regional y nacional, lo que no excluye la interacción con el nivel internacional, cuya comprensión es también necesaria para pensar en dinámicas regionales. Se utiliza la amplitud teórica de los Complejos Regionales de Seguridad, ya que, de acuerdo con esta proposición, los problemas de seguridad que enfrentan los Estados de una región determinada no pueden pensarse por separado, lo que abre la posibilidad de pensar estos temas en conjunto, por la vía de las instituciones.

Palabras clave:Seguridad regional; América del Sur; Complexos Regionales de Seguridad. 


\section{INTRODUÇÃO}

Ao se refletir sobre a lógica regional da segurança e defesa na América do Sul, é preciso antes entender as dinâmicas da cooperação que tem sido construída ao longo dos anos sob descontinuidades e transformações. São percebidas características particulares nas formas de regionalismo levadas adiante na região, as quais podem ser melhor compreendidas se considerado o histórico de instituições de âmbito hemisférico no continente americano. Tal histórico é especialmente relevante nos temas da defesa, em que a proximidade geográfica dos EUA interfere diretamente no desenrolar dos grupos regionais criados.

Inserido na discussão da segurança regional, o objetivo central aqui é analisar a construção de um componente de segurança e defesa na América do Sul, ao verificar se, entre os anos de 2008 e 2016, o Conselho de Defesa Sul-Americano (CDS) pode ser entendido como parte do processo de concepção de uma identidade sul-americana em defesa. Buscamos responder ao seguinte problema de pesquisa: em seus primeiros anos de funcionamento, a agenda e estrutura do CDS se adequaram ou não às necessidades da região? Nosso questionamento se justifica na medida em que foi possível identificar avanços fundamentais para o processo de cooperação em defesa na América do Sul com a criação do CDS, mas, ao longo dos anos, esses avanços não demonstraram sustentação suficiente que permitisse a consolidação de um pensamento comum sul-americano em defesa.

Em termos metodológicos, neste trabalho a pesquisa bibliográfica foi a principal técnica usada, tanto para fontes primárias - como o estatuto do CDS - quanto secundárias. Pautamonos ainda pela abordagem qualitativa e pelo método hipotético-dedutivo, e, como marco teórico, utilizamos a proposição da Escola de Copenhague acerca dos complexos regionais de segurança (CRS), segundo a qual os problemas de segurança de uma região encontram-se intimamente conectados e não podem ser de fato compreendidos de maneira isolada.

O texto encontra-se dividido em quatro partes. Primeiro há uma discussão teórica sobre o Complexo Regional Sul-Americano, de forma a evidenciar as ferramentas empregadas na análise do objeto. Em seguida é feita uma breve revisão histórica dos processos de cooperação hemisféricos levados a cabo no continente americano a partir dos anos 1940, para que se entenda a origem da cooperação regional em defesa. Na terceira parte, o assunto principal é a criação e consolidação da União de Nações Sul-Americanas (UNASUL), um organismo de 
cooperação importante em termos de governança política da América do Sul. Finalmente, ao abordar a construção da cooperação em segurança e defesa, a quarta parte focaliza o Conselho de Defesa Sul-Americano, analisando toda sua estrutura, bem como sua relevância para o avanço de uma possível identidade de defesa sul-americana.

\section{COMPLEXO REGIONAL DE SEGURANÇA SUL-AMERICANO: DISCUSSÃO TEÓRICA}

Ao situar nossa reflexão no nível de análise regional, a América do Sul é aqui pensada sob a lente teórica dos complexos regionais de segurança, proposta por Buzan e Waever (2003). A referida teoria propõe a definição do complexo regional de segurança como "um conjunto de unidades em que os principais processos de securitização, dessecuritização, ou ambos, são tão interligados que seus problemas de segurança não podem ser razoavelmente separados uns dos outros" ${ }^{1}$ (BUZAN, WAEVER, 2003, p. 44, tradução livre do original em inglês). Em outras palavras, a lógica dos CRSs está intimamente ligada ao elemento da interdependência entre as questões de segurança dos Estados de determinada região, pois torna-se impossível compreender todas as problemáticas de segurança de um Estado ao estudá-lo de forma isolada.

É importante retomar a caracterização tipológica dos CRSs para compreender as diferenças de polaridade que determinam os tipos de complexos. Isso posto, há dois tipos de CRS: padrão e centrado. Os complexos categorizados como tipo padrão são aqueles em que não há a presença de uma potência global e a própria polaridade regional balanceia o poder. Já os complexos de tipo centrado se subdividem em três formas, podendo ser unipolares em que o polo é uma grande potência; unipolares, porém o polo constituído de uma superpotência; ou ainda centrados, porém sem a existência de um poder regional, o qual é exercido por instituições. Além destes três tipos, foi proposto um quarto tipo de modelo centrado unipolar, no qual o polo é constituído por uma potência de nível regional, mas que

\footnotetext{
1 "A set of units whose major processes of securitization, desecuritisation, or both are so interlinked that their security problems cannot reasonably be analyzed or resolved apart from one another" (BUZAN, WAEVER, 2003, p. 44).
} 
não chega a ser uma potência global. Para os teóricos, contudo, não foi possível identificar no cenário internacional um modelo de complexo regional que seja deste tipo, por isso o quarto modelo é sugerido como uma opção extra (BUZAN, WAEVER, 2003).

Com base na tipologia de análise descrita, o complexo regional da América do Sul é caracterizado como padrão, pois não há presença de um polo de poder global e, ainda, tende a se dividir em dois subcomplexos: Cone Sul e Norte Andino. Além disso, a situação de proximidade com os EUA é um fator importante, mas que, após o fim da Guerra Fria, tomou outros contornos, pois a América do Sul deixou de ser prioridade na linha de ação internacional estadunidense, o que abriu espaço para uma maior atuação regional por parte de Brasil e Argentina, de maneira a buscar um distanciamento dos EUA que permitisse 0 reforço do regionalismo em âmbito sul-americano (BUZAN, WAEVER, 2003).

Sobre os subcomplexos, a área referente ao Norte Andino corresponde àqueles países da Comunidade Andina de Nações e é considerada instável, devido à alta ocorrência de conflitos armados relacionados principalmente com questões de narcotráfico. Já o Cone Sul é a área que se refere aos países da formação original do Mercosul, a qual, em comparação com o outro subcomplexo, pode ser considerada estável, muito em virtude do esforço em termos de integração observado por parte dos sócios do Mercosul em seus anos iniciais (PEDROSO, 2015).

Por outro lado, os autores Fuccille e Rezende (2013) entendem que o complexo regional sul-americano se adequa melhor a uma outra categoria, que não aquela proposta por Buzan e Waever (2003). Para eles, devido ao papel predominante exercido pelo Brasil nas dinâmicas de segurança da região², é mais interessante pensar o CRS da América do Sul em termos de um complexo centrado, com o Brasil exercendo a condição de potência unipolar e determinando os contornos de segurança. Esse cenário se tornou possível principalmente pela diminuição da importância estratégica da América do Sul na agenda dos EUA, o que gerou um espaço possível de ser preenchido por atores regionais interessados em ocupar o papel de

\footnotetext{
2 Para fins de análise no âmbito da teoria dos Complexos Regionais de Segurança, o papel de liderança do Brasil na região é considerado predominante devido à sua influência tanto nas dinâmicas do Cone Norte quanto do Cone Sul. Entretanto, Malamud (2013) desenvolve um raciocínio que questiona a liderança regional do Brasil, numa perspectiva que o considera um Estado bifronte. Para mais informações, ver Malamud (2011) e (2013).
} 
liderança. Logo, para Fuccille e Rezende (2013), o CRS da América do Sul se enquadra no quarto modelo de CRS centrado proposto por Buzan e Waever (2003), do qual, até então, não havia sido identificado nenhum exemplo.

Assim, a partir desta caracterização teórica, busca-se compreender as dinâmicas de segurança que perpassam a América do Sul, uma região na qual se estabeleceu uma situação de "paz violenta", isto é, há demonstração de força ao invés desta ser necessariamente empregada (MARES, 2001).

\section{ANTECEDENTES DA COOPERAÇÃO EM DEFESA NA AMÉRICA DO SUL $(1940-2000)$}

As dinâmicas que antecedem o nível regional da cooperação em segurança e defesa na América do Sul têm abrangência hemisférica, posto que os organismos instituídos durante a II Guerra Mundial e a Guerra Fria estavam inseridos numa lógica de segurança continental. Por este prisma, a compreensão do contexto que fez possível a criação do CDS remonta aos antecedentes da cooperação em defesa no continente americano como um todo, pois durante todo o século $X X$ essas questões foram pensadas numa perspectiva interamericana e, principalmente, a partir dos interesses estadunidenses para a região. Portanto, as instituições criadas nesse período são de caráter hemisférico e incluem também o complexo regional da América do Norte, além do CRS sul-americano.

Neste sentido, Abdul-Hak (2013) divide historicamente as relações interamericanas de defesa e segurança em quatro fases ${ }^{3}$, em que a primeira está entre 1889 e 1933 e foi marcada pelo pan-americanismo clássico; a segunda abrange os anos da Política de Boa Vizinhança e vai de 1933 até 1950; a terceira fase, entre 1950 e 1990, foi marcada pelo desenvolvimento da doutrina da contrainsurreição; e a quarta, que teve início nos anos 1990 e perdura até os dias atuais. A partir desta divisão, a criação das instituições de defesa antecedentes ao CDS

\footnotetext{
${ }^{3}$ Para mais detalhes a respeito das quatro fases das relações interamericanas em defesa e segurança, ver: AbdulHak, 2013, p. 39.
} 
está situada na segunda fase, mais especificamente na década de 1940, em um contexto que abrange a II Guerra Mundial e seu fim, e o início da Guerra Fria.

É precisamente esse contexto internacional, que se agrava ao final dos anos 1930, que leva os EUA a uma postura de valorizar a cooperação em termos militares e criar os pilares do Sistema Militar Interamericano (SMI). Este sistema inclui a Junta Interamericana de Defesa (JID), o Tratado Interamericano de Assistência Recíproca (TIAR), a Organização dos Estados Americanos (OEA) e o Pacto de Bogotá e, apesar de enfraquecido frente às diferentes dinâmicas das chamadas "novas ameaças", ainda está em vigor. É esse cenário de instituições hemisféricas o antecedente imediato da cooperação em defesa na América do Sul, algo que confere maior importância à iniciativa que ganhou formato regional com o CDS.

A JID foi criada em 1942, na Conferência do Rio de Janeiro, com o objetivo de planejar a defesa contra agressões externas no âmbito hemisférico. Seu caráter consultivo e político resultou em uma baixa capacidade de tomada de decisões vinculantes, apesar de promover um espaço formal de participação dos Estados latino-americanos e caribenhos na defesa do continente (PAGLIARI, 2006). Entretanto, é possível conceber este mecanismo como uma expressão da subordinação das forças armadas latino-americanas à visão estratégica dos EUA, além de ser uma forma de restringir a autonomia militar desses Estados (MARTINS FILHO, 1999).

O próximo pilar que passa a compor o Sistema Militar Interamericano é o TIAR, criado em 1947, mas cujas origens estão na Conferência sobre os Problemas de Guerra e Paz quando da assinatura da Ata de Chapultepec (1945). Este documento, por meio de uma declaração de "Assistência Recíproca e Solidariedade Americana", lançou as bases para a assinatura do TIAR, dois anos mais tarde, com o intuito de reafirmar a solidariedade hemisférica, além de enunciar princípios que seriam recolhidos também pela Carta da OEA (ARRIGHI, 2004). A novidade em termos de cooperação em defesa trazida pelo Tratado foi o estabelecimento de um mecanismo de defesa coletivo entre os EUA e os demais países latino-americanos, cuja ideia principal era que, se um Estado americano fosse atacado, seria formada uma frente comum para responder ao ataque, respaldada pela legítima defesa individual ou coletiva (PAGLIARI, 2006). 
Conforme observado por Abdul-Hak (2013, p. 41), o fato de o TIAR ter poucas exigências práticas, como a não obrigatoriedade no fornecimento de tropas, demonstra a pouca relevância atribuída pelos EUA ao poder militar dos latino-americanos em situações de combate. Mais do que isso, este organismo explicita os reais objetivos dos EUA para o Sistema Militar Interamericano, os quais se restringiam a criar uma reserva de mercado bélico para contrapor a concorrência europeia e manter estável a ordem regional, de forma a facilitar a concentração de recursos militares estadunidenses em outras regiões, como Oriente Médio, Europa e Ásia Pacífico. Apesar de o Tratado haver sido invocado 19 vezes no período em que esteve vigente, sua aplicação efetiva só se deu em oito situações, além de haver ocorrido outras intervenções na América Latina que não foram amparadas. Um exemplo dessas intervenções, cuja repercussão levou a uma perda de credibilidade do TIAR por parte dos latino-americanos, foi a Guerra das Malvinas (1982), quando os EUA se recusaram a apoiar um país do continente que estava sob ataque. A partir desta situação, foi inviabilizada a prerrogativa de invocar o Tratado como mecanismo de ajuda mútua do sistema interamericano (PAGLIARI, 2006).

Já ao final dos anos 1940, são adotadas a Carta da OEA e o Pacto de Bogotá, ambos em 1948. A OEA foi formada durante a Nona Conferência Interamericana, realizada em Bogotá, com o intuito de reafirmar o compromisso hemisférico com a segurança coletiva. A Organização segue as diretrizes acordadas no TIAR, algo importante institucionalmente, pois o fato de o Tratado ter sido anterior à própria OEA foi um elemento que comprometia seu funcionamento, considerando-se que houve a celebração de um tratado de defesa antes mesmo de haver sido formalmente constituída uma organização regional (XAVIER, 2010). Assim, inicialmente foram 21 Estados a ratificar a Carta da OEA, mas, posteriormente, todos os Estados do continente aderiram à instituição (ARRIGHI, 2004). Neste sentido, é importante ressaltar que Cuba foi excluída da OEA em 1962, devido ao seu alinhamento com a URSS. Tal situação só veio a mudar em 2009, quando a suspensão do país foi revogada durante a 39ạ Assembleia Geral da OEA.

Por fim, também na Nona Conferência, foi adotado o Tratado Americano de Soluções Pacíficas, ou Pacto de Bogotá. O objetivo deste Tratado é obrigar que seja pacífica a resolução 
de controvérsias entre os Estados americanos, por meio de procedimentos que não envolvam a ameaça, o uso da força, bem como qualquer outra forma de coação. Logo, "a Carta deu o quadro institucional; o Pacto de Bogotá assegurou a solução pacífica das controvérsias; o TIAR, adotado anteriormente, proporcionou um quadro de defesa conjunta em caso de ataque" (ARRIGHI, 2004, p. 21). Assim, por meio desses quatro mecanismos instituídos ao longo dos anos 1940, o Sistema Militar Interamericano foi formulado de maneira a garantir que os conflitos entre os Estados americanos fossem resolvidos pacificamente.

Outrossim, durante a terceira fase das relações de defesa interamericanas (19501990), foi possível observar um enfraquecimento desses mecanismos, causado em grande medida pela incapacidade demonstrada pela OEA em controlar o emprego da força pelos próprios EUA. Situações como a invasão da República Dominicana (1965), a desestabilização da América Central (anos 1980), as intervenções armadas em Granada (1983) e no Panamá (1989), além da já mencionada Guerra das Malvinas (1982) tornaram possível questionar a validade do SMI (ABDUL-HAK, 2013). Por conseguinte, a partir dos anos 1990 ocorre uma tentativa de revitalização desse sistema, através da criação de mecanismos de caráter subregional de segurança. Por meio do diálogo no âmbito regional, concluiu-se que a institucionalidade hemisférica perdeu força devido ao comportamento dos EUA, que, a despeito da agenda multilateral, priorizava seus compromissos bilaterais com os demais países americanos e esvaziava o sentido e capacidade de ação daquelas instituições (PAGLIARI, 2006).

É possível depreender que foi esse cenário forjado nos anos 1940 que possibilitou, mais tarde, a estruturação de um pensamento de âmbito regional na América do Sul em termos de defesa. A incapacidade demonstrada pelo SMI de oferecer respostas válidas às ameaças que passaram a compor a agenda de segurança do pós-Guerra Fria abriu espaço para conceber outras maneiras possíveis de pensar os problemas em comum enfrentados regionalmente. Conforme assinalado por Cepik (2009, p. 230):

We part from the assumption that the already existing collective security system in the Americas, the Organization for the American States (OAS), is not sufficient for the current challenges and threats that are present in the continent. In this sense UNASUR draws a different approach from that which has already been assessed by 
the OAS: aiming at a more autonomous policy, it excludes the United States from South American security affairs by replacing the conflict resolution mechanisms of the OAS, therefore optimizing the recognition of South American interests ${ }^{4}$.

Assim, numa lógica que buscava alternativas às formulações hemisféricas, há a criação da União de Nações Sul-Americanas (UNASUL) em 2008, a qual não deve ser considerada como processo de integração, mas sim como um fenômeno de cooperação regional, com muitos propósitos aglutinados e focada na concertação política (FUCCILLE, 2018). É no escopo desta instituição que é originado o Conselho de Defesa Sul-Americano (CDS), órgão que representa o esforço dos países-membros da UNASUL de promover a cooperação também em termos de segurança e defesa.

Neste sentido, há que se olhar com atenção para a distinção entre integração e cooperação regional ${ }^{5}$. A integração regional, por um lado, é um processo mais amplo, no qual os interesses dos Estados são redefinidos em termos regionais, ao invés de manterem caráter puramente nacional, e o antigo conjunto de valores particulares nacionais é suplantado por um novo, maior e geograficamente delineado conjunto de valores (HAAS, 2004). Por outro lado, a cooperação é um processo definido pela coordenação política entre os atores envolvidos, que ajustam seus comportamentos com o objetivo de atingir expectativas em comum (KEOHANE, 1984). Por essa distinção é necessário cuidado ao caracterizar as instituições criadas regionalmente na América Latina, pois a grande maioria corresponde a processos de cooperação, como é o caso da UNASUL.

\footnotetext{
4 "Partimos do pressuposto de que o sistema de segurança coletiva já existente nas Américas, a Organização dos Estados Americanos (OEA), não é suficiente para os desafios e ameaças atuais que estão presentes no continente. Nesse sentido, a UNASUL traça uma abordagem diferente daquela que já foi avaliada pela OEA: visando uma política mais autônoma, exclui os Estados Unidos dos assuntos de segurança sul-americanos, substituindo os mecanismos de resolução de conflitos da OEA, otimizando, assim, o reconhecimento dos interesses da América do Sul" (CEPIK, 2009, p. 320, tradução livre do original em inglês).

${ }^{5}$ Para um aprofundamento sobre os processos regionais ver: Sanahuja (2016), Mariano (2015), Milner (2011) e Malamud (2004).
} 


\section{UNIÃO DE NAÇÕES SUL-AMERICANAS: UM NOVO OLHAR PARA PENSAR A COOPERAÇÃO?}

A criação da União de Nações Sul-Americanas ocorreu durante a mudança observada na dinâmica do regionalismo na América do Sul a partir dos anos 2000. A iniciativa dos países da região em buscar maior autonomia frente à presença estadunidense nas instituições regionais se tornou factível em alternativas como a ALBA-TCP e, principalmente, a UNASUL. Esta última, que num primeiro momento conta com grande força política, demonstra potencial de aprofundamento num projeto político de integração, de forma a responder aos desafios da globalização para o subcontinente.

Neste sentido, ficou evidenciada a necessidade sul-americana de pensar uma estratégia capaz de contrabalancear a influência dos EUA na região, principalmente ao considerar a instalação de uma base militar no Equador, bem como a implantação do plano Colômbia, ambas ações bilaterais na região andina, no início dos anos 2000, por parte dos EUA, que não foram recebidas com satisfação por alguns governos sul-americanos (FAWCETT, 2005; MONTEIRO, 2014). Portanto, nesse período é possível verificar a existência de um multilateralismo regional pós-hegemônico, que buscava facilitar ações de âmbito intergovernamental, mas também fazer frente às tendências estadunidenses de interferir nas questões regionais da América do Sul (SALTALAMACCHIA, 2014).

O esforço que culminou com a criação da UNASUL conta com um elemento importante de conscientização, por parte das classes governantes locais, a respeito de uma mentalidade de ruptura com a tradicional tendência interpretativa de fragmentar o subcontinente. Devese destacar ainda que a ocorrência de uma maioria de governos de cunho social-progressista na região é também um elemento importante na compreensão da criação da UNASUL. Porém, apesar de significar a busca por mudanças reais no significado dos processos regionais para a América do Sul, a institucionalidade do organismo não se consolidou de maneira forte o bastante para alterar o status quo da região e equalizar as latentes assimetrias existentes entre os países (ZURITA, 2009). 
Desta forma, a articulação que deu origem à UNASUL foi baseada em componentes políticos, pensada para absorver também os temas de matriz econômica, mas principalmente para ir além dessa esfera. Essa decisão estritamente política foi representativa para a regionalização sul-americana, na medida em que rompeu com uma história de tentativas de integração cujas prioridades favoreciam a área comercial, como nos exemplos da ALALC, ALADI, Mercosul, ALCA e CAN (NAFALSKI, 2010).

É importante destacar, nesse contexto, que o formato institucional percebido nas alternativas de regionalização latino-americanas de cunho político tem um baixo nível de institucionalização em sua estrutura, característica esta que deve ser analisada de forma particular. No caso europeu, por exemplo, molduras que priorizavam o supranacionalismo foram usadas de maneira a evitar a reincidência de guerras entre os Estados de um mesmo continente, o que difere substancialmente da situação da América do Sul, onde se entende a funcionalidade do multilateralismo como uma oportunidade de concertação econômica ou, no caso da UNASUL, política (SALTALAMACCHIA, 2015).

Por um lado, ao entender o modelo institucional da UNASUL como uma tentativa de não seguir aqueles padrões de integração estabelecidos, como no exemplo do Mercosul, cabe perguntar se esta nova forma de regionalismo buscada na América do Sul tem a organicidade, sistematização e burocracia necessárias ao pleno funcionamento da organização. Por outro lado, fica também a inquietação sobre a possibilidade de essa escolha institucional significar a tentativa de uma nova arquitetura de solidariedade sul-americana, por se constituir de ferramentas diferentes daquelas propostas em modelos neoliberais. Porém, é fato que uma novidade importante em termos de aprofundamento da regionalização veio a aparecer, qual seja, a incorporação da temática de segurança e defesa à pauta da UNASUL (DIAMINT, 2013), algo que ainda não tinha sido pensado sob a ótica da cooperação sul-americana, salvo na débil tentativa por parte da ALBA-TCP em lançar forças armadas conjuntas na região6 ${ }^{6}$

\footnotetext{
${ }^{6}$ Esta iniciativa será detalhada na próxima seção deste artigo.
} 


\section{Contexto político de formação da UNASUL}

Para entender a estrutura institucional que caracteriza a União das Nações SulAmericanas, bem como seu papel em termos de segurança e defesa na região da América do Sul, é necessário antes compreender o contexto político à época da articulação para sua formação. Os antecedentes mais recentes que compõem tal contexto se situam nos anos 2000, quando mudanças importantes ocorrem no cenário internacional no sentido de criticar a globalização e a ordem político-econômica daquele momento, como as críticas ao Consenso de Washington (1989), e, no Brasil, o Primeiro Fórum Social Mundial (2001), organizado pelo Partido dos Trabalhadores (PT) e pela Associação pela Tributação das Transações Financeiras para Ajuda aos Cidadãos (ATTAC) (SANCHÉZ, 2015).

Neste sentido, a deterioração socioeconômica que se estabeleceu na década de 1990 em decorrência das medidas neoliberais em vigor encontrou resposta na paulatina ascensão de governos identificados com as questões sociais a partir dos anos 2000 na América do Sul, algo apontado pelos estudiosos como onda rosa, primavera sul-americana, entre outros, pelo fato de estes governos possuírem características progressistas, identificados com a esquerda ou centro-esquerda. Esta resposta teve início com a eleição de Hugo Chávez na Venezuela (1999), e seguiu com Lula da Silva no Brasil (2003), Néstor Kirchner na Argentina (2003), Tabaré Vázquez no Uruguai (2005), Evo Morales na Bolívia (2006), Rafael Correa no Equador (2007) e Fernando Lugo no Paraguai (2008) (FUCCILLE, 2014, p. 113).

As consequências dessa nova onda de governos foram sentidas tanto em âmbito doméstico quanto no plano internacional. Na dimensão doméstica, foram implementadas políticas econômicas de cunho intervencionista, além de diferentes políticas sociais, que resultaram em milhões de pessoas deixando a situação de pobreza extrema. No plano internacional, a adoção de políticas externas que priorizavam a autonomia foi a principal marca desses governos, ao buscar construir um regionalismo de caráter político e heterogêneo (NERY, 2016).

Logo, precisamente no ano 2000, ocorreu em Brasília uma reunião de presidentes da América do Sul convocada pelo então presidente brasileiro Fernando Henrique Cardoso (1995-2003), que foi um evento marcante, pois veio a reunir pela primeira vez todos os 
presidentes da região exclusivamente, ou seja, não houve a participação de nenhum Estado externo. Esta primeira cúpula resultou na criação de uma Zona de Paz Sul-Americana, algo importante, pois aproximou os Estados andinos dos Estados do Mercosul e contribuiu para um pensamento geopolítico em termos de América do Sul. Ainda, foram lançadas nesta cúpula as bases para a Iniciativa para Integração da Infraestrutura Regional Sul-Americana (IIRSA) ${ }^{7}$ (MONTEIRO, 2014).

Assim, a substancial transformação no cenário político sul-americano teve impacto direto para que fosse possível pensar a criação de instituições com um perfil diferente daquele predominante até então. Neste contexto, ao buscar alternativas para promover uma real aproximação entre os países da América do Sul, dois projetos principais de instituições foram apresentados pelas lideranças de Brasil e Venezuela, o que levou a uma série de cúpulas presidenciais, bem como conversas paralelas e negociações bilaterais, cujo resultado foi o estabelecimento da UNASUL.

Apesar da disputa histórica por poder na região ser entre Brasil e Argentina, os laços construídos no âmbito do Mercosul aproximaram as duas potências regionais ${ }^{8}$. Isto dirimiu o clima de rivalidade, ao mesmo tempo em que a Venezuela passou a se destacar na tentativa de financiar iniciativas de âmbito regional, pois vivia um período de bonança graças ao alto preço dos barris de petróleo, que permitiu uma capacidade econômica mais forte (PEDROSO, 2015). Portanto, dois projetos de integração concorrentes foram lançados, algo que contribuiu de certa forma para uma perda de força nos ímpetos da integração, ao evidenciar as dificuldades entre as lideranças nacionais para encontrar um projeto comum.

Por parte da Venezuela, o projeto de integração bolivariano lançado possuía uma tônica geopolítica, por ser marcado por um conteúdo anti-imperialista, antiamericano e que se contrapunha à hegemonia estadunidense na América Latina em geral. Ademais, o objetivo era tornar a região um polo de poder capaz de se opor às medidas neoliberais. Por sua vez, o

\footnotetext{
${ }^{7}$ A IIRSA foi a primeira instituição formada pelos doze países da América do Sul, criada no ano 2000. 0 principal objetivo da instituição era promover o aprimoramento da infraestrutura na América do Sul, de forma a interligar fisicamente as principais regiões econômicas. No ano de 2009, a IIRSA é incorporada à UNASUL por meio do Conselho Sul-Americano de Infraestrutura e Planejamento (COSIPLAN). Para mais informações sobre os dez primeiros anos de funcionamento da IIRSA ver Honório (2013).

8 Para uma compreensão mais aprofundada sobre as relações Brasil-Argentina ver Saraiva (2012) e Merke (2008).
} 
Brasil apresentou uma proposta voltada para o desenvolvimento da região, ao priorizar avanços em áreas que pudessem contribuir para o incremento socioeconômico, como energia e logística, além de reforçar a dimensão política (PEDROSO, 2015).

O resultado dessa divergência de interesses foi uma tensão a respeito das características da nova instituição sul-americana, o que gerou dificuldades em termos de construção de consensos. A percepção destoante entre os governos de Brasil e Venezuela a respeito da função e efetividade da UNASUL significou um impasse nas negociações por parte de Chávez, o qual a equipe diplomática brasileira, principalmente na figura do chanceler Celso Amorim, buscou dirimir por meio de conversas de bastidores. Contudo, mesmo sob um ambiente de incerteza quanto ao desenho institucional do novo organismo, foi possível lançar a Comunidade Sul-Americana de Nações (CASA), no ano de 2004, por meio da Declaração de Cusco sobre a Comunidade Sul-Americana de Nações, na III Cúpula Presidencial da América do Sul (NAFALSKI, 2010).

Finalmente, após superadas as divergências sobre o desenho institucional por meio de sucessivos encontros entre os países sul-americanos nos anos de 2005 e 2006 ${ }^{9}$, alterou-se também o nome da organização, que, por sugestão de Hugo Chávez, passou a ser a União de Nações Sul-Americanas, algo que serviria para reforçar o valor político da iniciativa. Logo, além de ser apenas uma alteração estética, a partir de 2007 a UNASUL passou a ser dotada de personalidade jurídica, e, portanto, possui o status de organismo internacional (STELLA, 2012).

Neste sentido, a despeito dos avanços em termos de cooperação regional, as reais pretensões por trás da proposta da UNASUL evidenciam a importância da América do Sul para a política externa brasileira, pois para o Brasil a vinculação com a América Latina representava maior dificuldade em negociações comerciais com os EUA, o que levou o país a buscar um distanciamento do âmbito latino-americano, para então dar mais ênfase ao espaço sulamericano. Assim, a UNASUL representa a estratégia de inserção internacional construída pela

\footnotetext{
${ }^{9}$ Após o lançamento da CASA, em 2004, os Estados membros se reuniram oficialmente no ano de 2005 para a I Reunião de Chefes de Estado da Comunidade Sul-Americana de Nações, no Brasil, e para tomar a decisão que criou a Comissão Estratégica de Reflexão sobre o Processo de Integração Sul-Americana, no Uruguai. No ano de 2006, houve a II Cúpula de Chefes de Estado da Comunidade Sul-Americana de Nações, da qual resultou a Declaração de Cochabamba, importante por estabelecer as prioridades da integração e semear a proposta de uma união de nações sul-americana (MONTEIRO, 2014).
} 
política externa brasileira, ao considerar a integração regional como o melhor caminho para tal inserção. Há que se observar, contudo, que a despeito de ter sido uma iniciativa lançada pelo Brasil, as dinâmicas no interior da instituição se acomodaram ao jogo político entre os doze países membros, ou seja, a despeito da tentativa brasileira de liderança, a UNASUL atuava sob uma dinâmica própria, a qual não necessariamente estava atrelada às vontades do Brasil (SARAIVA, 2009, DIAMINT, 2013).

Por fim, é necessário destacar a importância de uma instituição nos moldes da UNASUL na região de direta influência dos EUA, considerando-se que o principal objetivo da política externa estadunidense é impedir o desenvolvimento de um polo de poder na região sulamericana capaz de desafiar sua hegemonia hemisférica. Desta forma, fica evidente o interesse por parte dos EUA em manter a América Latina, mas principalmente a América do Sul, fragmentada, para que a integração e a aproximação entre os países da região possam ser dificultadas, o que facilita a manutenção da influência estadunidense e contribui para diminuir a autonomia do subcontinente (NERY, 2016).

\section{Estrutura e desenvolvimento da UNASUL}

A partir da ratificação do Tratado Constitutivo da UNASUL, firmado em Brasília pelos doze países da América do Sul no ano de 2008, ficou estabelecido o documento legal que respalda o funcionamento da instituição e resguarda também o reconhecimento da personalidade jurídica internacional (UNASUL, 2008, art. 1).

O Tratado Constitutivo da UNASUL deve ser entendido como produto de uma longa série de negociações entre os países sul-americanos, cujas pretensões vão muito além de questões exclusivamente técnicas ou econômicas. Temas outrora marginalizados na agenda de integração da região foram retomados por meio da construção de novas prioridades, mas também foram incorporados aspectos que já haviam aparecido em outros organismos multilaterais da região, como a função da Secretaria Geral e os mecanismos de grupos de trabalho setoriais, além do Parlamento Sul-Americano (CARDONA, 2008; SÁNCHEZ, 2015).

A construção de consensos no interior da instituição, embora dificultosa devido à necessidade de aprovação por parte de cada um dos doze países membros, assegura a 
representatividade por igual entre todos, algo relevante ao se pensar a integração sulamericana, em que há países de tamanhos e proporções tão diferentes, como, por exemplo, Uruguai e Brasil. Assim, nenhuma decisão pode ser tomada se houver um Estado em desacordo, e isto garante que todos os países participarão dos processos decisórios. Ademais, se a fórmula do consenso não houvesse sido adotada, muito provavelmente a assinatura do Tratado não teria sido possível (SOLÓN, 2008).

Os conselhos setoriais criados no âmbito da UNASUL, que são respaldados pelo artigo 50 , demonstram a gradual formatação institucional durante o processo. Neste sentido, os conselhos representam uma nova prática no âmbito da integração regional, ao buscar o autoconhecimento da região por meio da proximidade com especialistas em áreas consideradas prioritárias, o que permite maior eficácia na construção das políticas voltadas a essas áreas. São criados doze conselhos, mas apenas o Conselho Energético Sul-Americano ${ }^{10}$, cuja sede fica na Venezuela, consta no texto do Tratado Constitutivo, devido à sua criação ter sido no ano anterior à assinatura do Tratado (CARVALHO, 2013).

Desta forma, a criação dos conselhos setoriais contribui com o intuito planteado pela UNASUL, qual seja, promover um aprofundamento nos níveis de cooperação para além dos indicadores econômicos, ao ampliar a participação da sociedade civil na instituição. 0 entendimento de que não apenas os chanceleres e chefas e chefes de Estado deveriam ser autoridades da instituição contribuiu para que os conselhos contassem com especialistas capazes de realizar diagnósticos sobre a situação de determinados temas caros ao processo de cooperação, bem como com os ministros responsáveis por esses assuntos nos países (CARDONA, 2008).

As percepções discutidas no âmbito dos conselhos resultam em informes periódicos, que são apresentados por parte dos altos funcionários setoriais ao Conselho de Delegadas e Delegados. A estruturação de conselhos específicos para pensar áreas substanciais ao desenvolvimento demonstra uma maturidade institucional na UNASUL. Especificamente em relação às questões de segurança e defesa, a diferenciação feita entre conselhos para pensar

\footnotetext{
${ }^{10} \mathrm{O}$ Conselho Energético Sul-Americano foi criado na mesma reunião em que foi alterado o nome da instituição de CASA para UNASUL, no ano de 2007, por meio da Declaração de Margarita.
} 
problemáticas de segurança cidadã e drogas, bem como cooperação em defesa, favorece o aprofundamento de estratégias específicas para cada fim.

Destarte, a próxima sessão tem como foco principal o Conselho de Defesa SulAmericano, que faz parte de uma incipiente tentativa de pensar a lógica da defesa em termos regionais e significa, portanto, um processo de cooperação mais robusto.

\section{COOPERAÇÃO EM DEFESA NO ÂMBITO DA AMÉRICA DO SUL}

Ao considerar a natureza da UNASUL enquanto um fórum de coordenação e concertação política, o objetivo de expandir as áreas nas quais se coopera aparece de forma orgânica. Como detalhado na sessão anterior, a criação de conselhos setoriais movimentou as engrenagens que permitiram dar uma nova dimensão ao projeto, ao analisar separadamente áreas que poderiam estruturar o aprofundamento da integração. Dentre as áreas priorizadas estão segurança e defesa, que são pensadas no âmbito de três conselhos diferentes, de forma a separar a problemática da segurança cidadã das questões de defesa. Assim, as possibilidades da cooperação em defesa entre os Estados membros, bem como as inflexões e peculiaridades do tema, são discutidas no Conselho de Defesa Sul-Americano, o qual deve ser entendido como o produto das modificações no tabuleiro do cenário internacional com o fim da Guerra Fria.

No caso da América do Sul, este novo cenário difere em grande medida daquele experimentado entre as décadas de 1960 e 1980, quando predominavam os governos ditatoriais na região e havia uma forte presença dos EUA na determinação do que deveria ser entendido como ameaça. Naquela época, a incipiente cooperação em assuntos de defesa foi provocada por dois fatores principais, quais sejam, os processos de redemocratização e a busca por alguma autonomia frente às imposições estadunidenses. Neste sentido, a determinação da ameaça comunista como principal inimigo a ser combatido em decorrência da Guerra Fria diminuiu a possibilidade de eclosão de conflitos interestatais na região e, ao mesmo tempo, elevou a percepção das rivalidades geopolíticas entre os governos, o que 
resultou em um clima de instabilidade que obstaculizou a cooperação em defesa nos anos seguintes (SOARES, 2008).

Assim, o desenrolar da Guerra Fria restringe o relacionamento entre os EUA e a América do Sul aos temas de segurança e defesa, mais especificamente à defesa das rotas marítimas no Atlântico Sul e à contenção interna da subversão (CABRAL, 2013), ao passo que o sistema interamericano de segurança hemisférica é estabelecido. Nesse sistema, é importante destacar, a partir dos anos 1940, a criação da Junta Interamericana de Defesa (JID), bem como do Tratado Interamericano de Assistência Recíproca (TIAR) e da Organização dos Estados Americanos (OEA), organizações empregadas para institucionalizar a agenda de segurança hemisférica durante a ordem bipolar a serviço dos interesses estadunidenses, o que significava, principalmente, afastar a ameaça do comunismo.

Ademais, com o intuito de assegurar a influência estadunidense sobre os países sulamericanos, foi elaborada também a Doutrina de Segurança Nacional, segundo a qual o inimigo a ser combatido deixava de ser externo e passava a ser interno, ou seja, a lógica da ameaça comunista era transferida para o âmbito doméstico. Essa doutrina foi exportada para todos os países do continente americano durante os anos da Guerra Fria (PÁDUA, MATHIAS, 2010).

A situação começou a mudar a partir dos anos 1980, quando os regimes militares perderam força, devido a dificuldades tanto internas quanto externas, e passaram a buscar a cooperação para o desenvolvimento como um fator de estabilidade regional. Neste contexto, com o intuito de restabelecer o continente das Américas como sua área de segurança nacional, os EUA passam a considerar o conceito da multidimensionalidade para pensar a segurança, o qual, segundo Saint-Pierre (2011, p. 409), "mistura indiscriminadamente vários elementos de natureza diferente [...] que requerem vários tipos de respostas".

Assim, a partir do fim da Guerra Fria, a versão da segurança multidimensional aparece como parte do Consenso de Washington (1989), demonstrando a preocupação estadunidense em reduzir o tamanho do Estado, além de reassegurar sua área de segurança nacional. Neste sentido, os EUA convocam no ano de 1995 a primeira Conferência de Ministros de Defesa das 
Américas $^{11}$ (CMDA), com o objetivo máximo de promover um espaço de discussão sobre as questões de defesa, bem como aprovar uma agenda hemisférica de segurança por meio da qual seria proposta uma lista de ameaças comuns ao continente. Estas ameaças, evidentemente, serviam aos interesses diretos dos EUA (CEPIK, 2005; SAINT-PIERRE, 2011).

Contudo, o modelo de segurança hemisférica imposto pelos EUA durante a Guerra Fria se mostrou insuficiente para lidar com os ímpetos da globalização, assim como para administrar as chamadas "novas ameaças". A pouca efetividade dos órgãos criados no âmbito pan-americano - como ficou evidente durante a Guerra das Malvinas ${ }^{12}$ quando o TIAR foi acionado - levou a uma erosão da legitimidade do modelo coletivo de segurança, algo que, somado à mudança de prioridades na estratégia de defesa estadunidense após os ataques de 11 de setembro de 2001, contribuiu para a consolidação da imagem de uma América do Sul passível de maior autonomia (AYERBE, 2002; FUCCILLE, 2016).

Neste sentido, ao considerar a subsequente atuação dos Estados sul-americanos, é possível concluir que houve uma percepção da incapacidade dos mecanismos institucionais hemisféricos em dar respostas às ameaças de segurança experimentadas pelo continente, inclusive às ameaças tradicionais ainda presentes. Além disso, as diferentes situações em termos de segurança que coexistiam/coexistem na região e que outrora eram vistas como variáveis da Guerra Fria foram redimensionadas, de maneira que a nova agenda de segurança hemisférica proposta por parte dos EUA não exclui a histórica agenda de ameaças enfrentadas pelos países da América do Sul (PAGLIARI, 2006).

Diante deste contexto, a cooperação nos assuntos de defesa no âmbito exclusivamente da América do Sul foi iniciada no nível bilateral, por meio de acordos que buscavam desenvolver a confiança mútua entre os Estados, como o Acordo de Cooperação para o Desenvolvimento e a Aplicação dos Usos Pacíficos da Energia Nuclear (1980), assinado entre Brasil e Argentina. Já nos anos 1990, especificamente na área do Cone Sul, o Mercosul

\footnotetext{
${ }^{11}$ A Conferência de Ministros de Defesa das Américas conta com 34 países membros, pertencentes ao continente americano. Após a primeira reunião convocada em 1995, a CMDA ocorreu novamente no ano de 1996 e, a partir de então, acontece a cada dois anos. A última reunião foi no Chile e a próxima, no ano de 2022, será no Brasil. 12 “Para muitos países, essa aliança americana [TIAR] perdera sentido após a Guerra das Malvinas em 1982, pois os EUA abstiveram-se de apoiar um país do continente, o que inviabilizou a invocação do TIAR como mecanismo de ajuda mútua do sistema interamericano" (PAGLIARI, 2006, p. 29).
} 
aparece como mecanismo de estabilidade sub-regional e inserção internacional; contudo, o forte teor do liberalismo econômico predominante nas iniciativas de integração à época contribuiu para que o bloco priorizasse os assuntos comerciais em detrimento de outras áreas. Desta forma, pese embora o bloco não tivesse a defesa como uma de suas pautas, a aproximação que ocorreu entre Brasil e Argentina foi importante para dessecuritizar as relações entre os dois Estados, algo que atingiu positivamente também ao Paraguai e ao Uruguai (ABDUL-HAK, 2013).

Destarte, a despeito de a cooperação em termos de segurança e defesa representar uma possibilidade importante no aprofundamento da integração regional, a América do Sul vislumbrou essa possibilidade de forma factível apenas a partir de 2008, com a consolidação do Conselho de Defesa Sul-Americano, algo que deveria reafirmar a importância dos progressos em concertação política no âmbito da UNASUL. Ainda, o CDS ganha força se considerada a díspar situação sul-americana, na qual é possível afirmar que a cooperação militar no Cone Sul experimentou um avanço que não encontra paralelos na região andina, onde persistem tensões de cunho político-militar que o órgão tem a potencialidade de dirimir.

\section{Formação do Conselho de Defesa Sul-Americano}

As diferentes visões políticas existentes na América do Sul, mesmo entre os governos progressistas que passaram a ocupar o poder na maioria dos Estados da região, produziram três posturas distintas diante da integração de forma geral, mas, também, no que se refere à segurança e defesa. A primeira postura foi aquela insuflada pela Venezuela, e que defendia o rechaço total às políticas neoliberais e buscava uma estratégia de contraposição ao poder e à influência dos EUA na América do Sul. A segunda é liderada pelo México no âmbito latinoamericano e possui como adeptos o Chile e a Colômbia, considera positiva a influência estadunidense na região e acredita que a integração em termos sub-regionais serve apenas de complemento à inserção internacional buscada nos termos das relações com os EUA. A terceira postura, liderada pela atuação do Brasil, propõe maior pragmatismo, ao reconhecer o peso dos EUA na região mas, ao mesmo tempo, buscar reduzir esse peso por meio da integração regional, sem confrontar diretamente a potência hegemônica (CARMO, 2012). 
Logo, em decorrência de alterações importantes na política externa estadunidense, bem como da ausência do México nos debates de âmbito sul-americano para pensar a integração, a postura sustentada por Chile e Colômbia é secundária, ainda que ambos os países detenham o poder da "não-decisão" para obstaculizar as propostas mais radicais com as quais não concordam. Portanto, no primeiro plano do debate sobre as propostas para a integração da América do Sul ficaram Brasil e Venezuela, ambos com percepções distintas acerca das prioridades que deveriam constituir a agenda de segurança sub-regional (CARMO, 2012).

A proposta venezuelana foi apresentada pela primeira vez durante a I Reunião de Presidentes da América do Sul (2000), em Brasília. Segundo aquele projeto, o objetivo final era a integração das Forças Armadas dos países da região, proposta esta que foi lapidada e reapresentada nos encontros de líderes seguintes. Afinada com os ímpetos chavistas de oposição radical à influência dos EUA, os aspectos bolivarianistas característicos da proposta venezuelana determinavam que a integração militar deveria ser antes fruto de uma integração política, que, a despeito das dificuldades de sua implementação, poderia levar à elaboração de uma política de defesa independente de influências externas, como dos EUA (PÁDUA, MATHIAS, 2010).

Assim, entre os anos de 2001 e 2005, a enfática atuação por parte da Venezuela em demonstrar que a ALCA, proposta de livre comércio feita pelos EUA, não deveria ser o destino dos países americanos ${ }^{13}$, mas sim uma opção, levou a uma aproximação entre este país e o Cone Sul, o que fez com que no ano seguinte, 2006, fosse protocolada a entrada venezuelana no Mercosul (CARMO, 2012). Contudo, às vésperas da assinatura do protocolo de adesão da Venezuela, ainda em 2006, durante uma reunião tríplice entre Brasil, Argentina e Venezuela, Chávez apresentou sua proposta para a criação de um Conselho de Defesa Sul-Americano, cuja estrutura seria composta pelos doze países sul-americanos. O órgão apresentado pelo

\footnotetext{
${ }^{13}$ Sobre a ALCA é importante considerar que "dentro da linha defendida pelo Brasil, o presidente Hugo Chávez apontava para a necessidade de fortalecer a integração andina, caribenha e amazônica como etapa prévia para a constituição da ALCA. A ALCA não poderia ser o projeto de integração dos países latino-americanos, pois não é possível reduzir um projeto de integração para a região somente ao econômico e comercial. A integração regional deve ser um instrumento do desenvolvimento e fortalecimento da soberania e independência dos países, deve gerar uma agenda política própria" (CARMO, 2012, p. 309).
} 
presidente venezuelano à época apontava para uma integração militar semelhante à OTAN, inclusive no nome, que seria Organização do Tratado do Atlântico Sul (OTAS) (OTÁLVORA, 2007).

A resposta imediata dos presidentes Lula e Kirchner foi de informar ao venezuelano que, até aquele momento, a concertação em defesa no âmbito do Mercosul se limitava à integração das indústrias bélica, aeronáutica e espacial. Entretanto, a recusa por parte dos sócios do Cone Sul em criar uma instância de defesa nos moldes de uma integração militar não significou o fim do projeto chavista para a região. Ainda no ano de 2006 foi realizado o seminário "Seguridad Regional, Integración y Fuerzas Armadas" de maneira conjunta pela secretaria do Parlamento Latino-Americano (Parlatino), Universidad Nacional Experimental Politécnica de la Fuerza Armada Nacional de Venezuela (UNEFA) e Frente Cívico-Militar Bolivariana (FRECIMIBOL). Este seminário reuniu diferentes instâncias e oficiais com o intuito máximo de formar uma Força Armada Regional sob o guarda-chuva da integração militar, algo que, todavia, não foi concretizado. Contudo, as discussões realizadas ali resultaram em uma decisão por parte de Venezuela, Bolívia e Cuba de iniciarem o projeto proposto por Chávez no âmbito da Alternativa Bolivariana para as Américas (ALBA-TCP), que tomou forma pautada em ideais anti-estadunidenses, socialistas e bolivarianos (PÁDUA; MATHIAS, 2010).

Por outro lado, a via de integração proposta pela liderança brasileira demonstrou maior pragmatismo, ao compreender a importância da integração para a região, bem como a dificuldade de confrontação direta aos EUA. Isso redundou em um maior apoio ao modelo de Conselho de Defesa Sul-Americano apresentado pelo Brasil, que representou uma alternativa àquele proposto por Chávez na medida em que trouxe a possibilidade de discutir temas comuns à defesa dos países da América do Sul, algo que incentiva o aprofundamento da cooperação e favorece a construção de medidas de confiança na região. Estas podem ser definidas como aqueles "processos políticos e/ou militares que objetivam mitigar e prevenir os efeitos negativos ou percepções erradas decorrentes dos 'dilemas de segurança' nas relações internacionais" (SAINT-PIERRE; PALÁCIOS JUNIOR, 2014, p. 23).

Neste sentido, Carmo (2012, p. 312) assinala uma modificação importante que se deu na política externa brasileira com relação à prioridade dada à América do Sul a partir do 
governo Lula da Silva. É fato que a região já era considerada estratégica durante os governos anteriores; contudo, a despeito de aproximações pontuais, principalmente no Cone Sul, não houve uma política estrutural por parte do Brasil para a América do Sul. A partir da mudança diante da perspectiva de integração sul-americana - que não significou o abandono das linhas tradicionais do Itamaraty - o governo brasileiro passou a "realizar costuras políticas" que construíssem sua maior influência na região, posto que os recursos militares e econômicos sustentados pelo Brasil não garantem esta influência. Um importante exemplo da mudança de postura do Brasil frente à América do Sul foi o lançamento da Estratégia Nacional de Defesa $^{14}$ (END), em 2008, que destaca como prioridade a busca de uma relação harmoniosa com os vizinhos, principalmente no que diz respeito à democracia e ao princípio da nãointervenção (SÁNCHEZ, 2015).

Portanto, a proposta começou a ser pensada a partir de 2006, e a atuação do Brasil que não convocou reuniões ou debates para promover a construção conjunta da iniciativa resultou em desconfianças por parte dos vizinhos, os quais temiam que o projeto fosse, de certa forma, "imposto". Logo, apesar do posterior esforço diplomático por parte do Ministério da Defesa brasileiro em divulgar a proposta do CDS, de maneira a tornar possível sua criação já em 2008 junto à reunião de fundação da UNASUL, a situação era de ausência de um entendimento claro sobre os alcances e objetivos pretendidos. Além disso, a forma com que o projeto foi administrado em seu início reverberou em uma percepção, por parte dos demais Estados sul-americanos, de imposição e imperialismo (SAINT-PIERRE, 2009).

Neste ínterim, o ministro da Defesa, Nelson Jobim, realizou um giro entre os países sulamericanos, com o intuito de apresentar a proposta, bem como garantir a adesão ao CDS. Contudo, é importante destacar que antes de a proposta haver sido apresentada na América do Sul, Jobim já havia explicado o desenho institucional pensado para o novo órgão à Junta Interamericana de Defesa e aos secretários de Defesa e de Estado dos EUA, algo visto como uma espécie de acerto de contas para obter o "aval" da superpotência na criação do CDS.

\footnotetext{
${ }^{14}$ A Estratégia Nacional de Defesa estabelece diretrizes em quatro eixos principais: organização e preparo das Forças Armadas; reorganização da Base Industrial de Defesa brasileira; composição dos efetivos das Forças Armadas; e o futuro do serviço militar obrigatório. Após sua criação, em 2008, a END veio a ser revisada em 2012, quando foi aprovada a atual versão que está em vigor (BRASIL, 2012).
} 
Ainda, ficou latente a necessidade de uma maior institucionalidade própria da América do Sul e alternativa à OEA com a crise entre a Colômbia e o Equador, quando forças oficiais colombianas adentraram o território equatoriano em meio ao combate da guerrilha e assassinaram o líder das Forças Armadas Revolucionárias da Colômbia (FARC), o que agitou os ânimos na região (DIAMINT, 2013; MONTEIRO, 2014).

Esse ambiente fez com que, de fato, a proposta formal do Conselho de Defesa SulAmericana fosse apresentada na fundação da UNASUL; no entanto, decidiu-se postergar a votação frente à iminência de uma possível derrota. Os presidentes peruano e colombiano colocaram em dúvida a consecução do CDS, que voltou a ser revisto oficialmente ainda em 2008, na ocasião de uma reunião da UNASUL para debater a mencionada crise entre Colômbia e Equador. Contudo, ainda neste novo encontro, o voto do então presidente colombiano, Álvaro Uribe, não ficou garantido a favor da criação do órgão de defesa, algo que só ocorreu em uma terceira Reunião Extraordinária das Chefas e Chefes de Estado e de Governo da UNASUL, em Salvador, que criou oficialmente, em 16 de dezembro de 2008, o Conselho de Defesa Sul-Americano (PEDROSO, 2015).

Neste sentido, ao se observar a cronologia das prioridades da agenda na consecução de UNASUL, fica evidente que os temas de segurança e defesa não aparecem com destaque. Isso provoca um questionamento sobre o que teria levado a uma mudança de perspectiva tal que possibilitasse a criação de um conselho de defesa ainda no ano de 2008 . Fuccille (2018, p. 7) assinala alguns fatos que, do ponto de vista brasileiro, foram fundamentais para que a cooperação em defesa recebesse algum protagonismo. Por meio de notas pessoais de conversas informais com membros do Itamaraty e do Ministério da Defesa brasileiro, o autor destaca:

Estavam (1) a possibilidade de transbordamento das chamadas novas ameaças a outros países, como o narcotráfico colombiano para o Brasil e a contenda envolvendo Colômbia, Equador e Venezuela pela morte de Raúl Reyes; (2) os conflitos sub regionais, como os contenciosos envolvendo Peru e Equador, Bolívia e Chile, entre outros; (3) os movimentos autóctones difundindo um sentimento separatista, como ilustram Bolívia e Paraguai; (4) frear os ímpetos bolivarianos na região, sobretudo via isolamento da Venezuela e/ou dos países integrantes da Aliança Bolivariana para as Américas (ALBA); (5) evitar uma corrida armamentista na região, com a adoção crescente de medidas de confiança mútua (CBMs); (6) 
solidificar o Atlântico Sul como uma área de paz, livre de armas nucleares e vital de projeção de poder ao Brasil, não permitindo a presença de potências extra regionais (como o caso do Reino Unido e a questão Malvinas/Falklands); (7) impedir a materialização de uma política estratégica de segurança hemisférica definida a partir dos Estados Unidos para o subcontinente; (8) rearticular a Base Industrial de Defesa (BID) com a América do Sul enquanto espaço primeiro à colocação de seus produtos; e, último mas não menos importante, (9) concretizar os objetivos estratégicos da Política Externa Brasileira de consolidação de um processo de integração sulamericano (Ibid).

Outrossim, a pretendida liderança do Brasil na América do Sul como componente substancial de sua inserção internacional deve ser considerada um elemento chave que impulsionou os esforços para a criação do CDS. A busca brasileira por prestígio e influência faz parte de seu projeto mais amplo de consolidar-se como uma potência regional, com o intuito de contribuir para que o país sul-americano possa alcançar um assento como membro permanente do Conselho de Segurança da ONU. Além disso, havia também o interesse do Brasil em reativar sua indústria de defesa, com o fim de ser o provedor regional em termos de indústria (YOPO, 2010; ARÁNGUIZ, 2013), algo mencionado explicitamente nos objetivos específicos do CDS: "promover o intercâmbio e a cooperação no âmbito da indústria de defesa" (UNASUL, 2008b, art. 5o f).

Por fim, é importante destacar que, a despeito da pequena adesão ao projeto chavista de cooperação em defesa para a região, houve uma compreensão da Venezuela de que a integração regional como ferramenta de promoção da multipolaridade no sistema internacional só seria possível com a participação do Brasil. Tal entendimento levou o país a buscar o apoio brasileiro, algo que ficou visível com a entrada da Venezuela no Mercosul15, bem como com a aceitação de medidas mais pragmáticas que pudessem tornar possíveis a UNASUL e o Banco do Sul (CARMO, 2012). O Brasil, por sua vez, manteve o caráter pragmático de sua política externa, ao "reconduzir" as ideias de Chávez, de forma a torná-las compatíveis com sua estratégia de liderança regional sul-americana (SANAHUJA, 2010; ARÁNGUIZ, 2013).

\footnotetext{
${ }^{15}$ A Venezuela passou a fazer parte do Mercosul como membro pleno a partir de 2012. Contudo, sua participação foi suspensa em 2016, por razão de descumprimento de normas internas do bloco.
} 


\section{Estrutura e desafios do Conselho de Defesa Sul-Americano}

A decisão da criação do Conselho de Defesa Sul-Americano foi tomada em Salvador, no Brasil, ao final do ano de 2008. As chefas e chefes de Estado e de governo ali reunidos reiteraram no preâmbulo do estatuto que a criação do novo órgão se encontrava respaldada pelo artigo 5o do Tratado Constitutivo da UNASUL e, além disso, aprovaram a proposta estatutária que já havia sido discutida em maio do mesmo ano. Assim, o CDS é criado como uma instância de consulta, cooperação e coordenação em matéria de defesa (UNASUL, 2008b, art. 19), estando sujeito aos princípios e propósitos das cartas das Nações Unidas e da OEA, bem como aos mandatos e decisões do Conselho de Chefas e Chefes de Estado e de governo da UNASUL (UNASUL, 2008b, art. 2ㅇ).

De acordo com seu estatuto, três objetivos gerais sumarizam os propósitos do Conselho, quais sejam: a) a consolidação da América do Sul como uma zona de paz, base para a estabilidade democrática e o desenvolvimento integral dos povos daqui oriundos, além de contribuir para a paz mundial (UNASUL, 2008b, art. 4ำa); b) a construção de uma identidade sul-americana em matéria de defesa, que considere as características sub-regionais e nacionais e contribua para o fortalecimento da unidade na América Latina e Caribe (UNASUL, 2008b, art. 40 b); e c) a geração de consensos que fortaleçam a cooperação regional em matéria de defesa (UNASUL, 2008b, art. 4o c). Além destes, foram elencados outros 11 objetivos específicos ${ }^{16}$.

\footnotetext{
${ }^{16}$ Consideramos importante trazer os objetivos específicos enumerados no estatuto do CDS, que são: (a) avançar gradualmente na análise e discussão dos elementos comuns de uma visão conjunta em matéria de defesa; (b) promover o intercâmbio de informação e análise sobre a situação regional e internacional, com o propósito de identificar os fatores de risco e ameaça que possam afetar a paz regional e mundial; (c) contribuir para a articulação de posições conjuntas da região em foros multilaterais sobre defesa, no marco do artigo 14 do Tratado Constitutivo da UNASUL; (d) avançar na construção de uma visão compartilhada a respeito das tarefas de defesa e promover o diálogo e a cooperação preferencial com outros países da América Latina e do Caribe; (e) fortalecer a adoção de medidas de fomento da confiança e difundir as lições aprendidas; (f) promover o intercâmbio e a cooperação no âmbito da indústria de defesa; (g) Fomentar o intercâmbio em matéria de formação e capacitação militar, facilitar processos de treinamento entre as Forças Armadas e promover a cooperação acadêmica dos centros de estudo de defesa; (h) compartilhar experiências e apoiar ações humanitárias como desminagem, prevenção, mitigação e assistência às vítimas de desastres naturais; (i) compartilhar experiências em operações de manutenção de paz das Nações Unidas; (j) intercambiar experiências sobre os processos de modernização dos Ministérios de Defesa e das Forças Armadas; (k) promover a incorporação da perspectiva de gênero no âmbito da defesa (UNASUL, 2008b, art. 5o).
} 
No que diz respeito à sua estrutura, o CDS é integrado pelas ministras e ministros de Defesa, ou seus equivalentes, dos países membros (UNASUL, 2008b, art. 6ㅇ). Cria-se também uma instância executiva no Conselho, composta pelas vices ministras e ministros de Defesa, ou seus equivalentes (UNASUL, 2008b, art. 8ํ). A presidência é exercida pelo mesmo país que ocupar a Presidência Pro Tempore da UNASUL, o qual fica encarregado de coordenar as atividades do Conselho (UNASUL, 2008b, art. 999). Ainda, há a prerrogativa da criação de grupos de trabalho, conforme entenda necessário a presidência, para a discussão de temas específicos considerados pertinentes (UNASUL, 2008b, art. 10).

Com relação ao seu funcionamento, fica determinado que haverá reuniões ordinárias anuais (UNASUL, 2008b, art. 12으), mas, também, a presidência poderá convocar reuniões extraordinárias segundo a solicitação dos países membros (UNASUL, 2008b, art. 15\%). Fica resguardada no estatuto também a tomada de decisões exclusivamente por meio do consenso (UNASUL, 2008b, art. 13ㅇ), em referência ao 12ㅇaㅁ artigo do Tratado Constitutivo da UNASUL. Além disso, é estabelecido que a entrada de novos membros no Conselho deverá seguir o estipulado no Tratado da UNASUL em seus artigos 19 e 20, que versam respectivamente sobre Estados Associados e Adesão de Novos Membros (UNASUL, 2008b, art. 17으).

Ainda sobre seu funcionamento, a linha de ação do CDS está baseada na aprovação e implementação de Planos de Ação, os quais reúnem um conjunto de medidas a serem realizadas no curto, médio ou longo prazo pelos países membros. Os planos, via de regra, são estabelecidos anualmente, estão divididos por eixos e contam com cronograma de reuniões, tarefas determinadas e a responsabilidade específica de cada Estado. Assim, o primeiro Plano de Ação foi aprovado no ano de 2009, com um período de vigência até 2010, mas foi validado também para o ano de 2011. Um dos resultados substanciais deste primeiro Plano de Ação foi a criação do Centro de Estudos Estratégicos de Defesa (CEED), proposto pela Argentina e que teve boa acolhida entre os demais membros (ABDUL-HAK, 2013). Contudo, deve se considerar que nem sempre todos os propósitos estabelecidos no Plano de Ação são executados com êxito. 
Neste sentido, o CEED ${ }^{17}$ foi pensado para servir de instância de assessoramento e consulta em assuntos de defesa, promover o intercâmbio de informações, contribuir na articulação de posições conjuntas entre os Estados, além de ser incumbido de elaborar as "medidas de confiança", bem como a metodologia de gastos em defesa no âmbito da UNASUL. Paralelamente à criação do CEED, foram promovidos pelo CDS Seminários em Defesa, cujos participantes englobavam funcionários do governo e acadêmicos, com o fim de discutir a modernização dos Ministérios de Defesa e buscar o avanço na construção de confiança. Entre os resultados diretos destes seminários emergem duas características fundamentais, que foram adotadas no âmbito da UNASUL. A primeira diz respeito ao incentivo para que os Estados membros desenvolvessem os seus Livros Brancos de Defesa; e a segunda define a publicidade dos gastos em defesa como principal mecanismo de transparência (DIAMINT, 2013; SAINT-PIERRE; PALÁCIOS JUNIOR, 2014).

Entretanto, a metodologia aplicada no processo de construção de confiança em defesa na América do Sul pode ser entendida como uma continuidade daqueles métodos já postos em prática no âmbito da ONU, da OEA e também da CEPAL. Além da questão dos Livros Brancos e da transparência de gastos, é possível identificar a baixa, quase nula, participação da sociedade civil nos debates como mais um elemento de aproximação entre o funcionamento do CDS e das demais instituições multilaterais mencionadas. Este fato acaba por resultar em um processo vertical, que mantém a predominância militar nos assuntos de defesa, ao passo em que outros setores, como a academia, não são incluídos (Ibid).

Fuccille (2018, p. 9) demonstra que, para além dos interesses majoritários das potências regionais - Brasil e Venezuela - na criação de um órgão para pensar a defesa, todos os países envolvidos tinham interesses próprios, que tiveram papel importante na estrutura final do CDS:

Da perspectiva argentina interessava aglutinar novos atores ao pleito de que "as Ilhas Malvinas são argentinas" e todos os desdobramentos que esta questão encerra; passando por um Paraguai acossado por problemas internos que culminou no

\footnotetext{
17 Vale mencionar também a criação da Escola Sul-Americana de Defesa (ESUDE), que, após um ano de estudo e diálogo, foi aprovada em 2014 durante a V Reunião Ordinária dos Ministros de Defesa do Conselho de Defesa Sul-Americano, em Paramaribo, no Suriname (VITELLI, 2017).
} 
surgimento do grupo guerrilheiro Exército do Povo Paraguaio (EPP); uma Venezuela que, ainda que aquém do modelo desejado pelo comandante Chávez, o enxergava como um importante instrumento para evitar o encapsulamento ou até mesmo uma ação direta por parte dos EUA; aos outros bolivarianos da região, Bolívia e Equador, a que interessava buscar garantias ante ações desestabilizadoras do tipo que se passou com e após o episódio de Angostura; para a Colômbia, ainda que reticente a princípio e temendo o isolamento, a possibilidade de um maior comprometimento e compreensão dos países vizinhos com o flagelo do conflito interno vivido por este; o Peru e Chile, com preparos e capacidades militares bastante distintos, buscavam reforçar a solução dos litígios por vias diplomáticas e eventualmente por meio de tribunais internacionais; ao norte Guiana e Suriname enxergando uma possibilidade para o aprofundamento de sua "sulamericanização" (em contraste com a histórica vocação caribenha); e, finalmente, com o CDS o Uruguai conseguia superar suas ressalvas a uma preocupante colaboração militar mercosulina entre Brasil e Argentina que causava grande desconforto em Montevidéu.

Sem embargo, a manutenção da tomada de decisão exclusivamente por consenso, somada à débil institucionalidade intergovernamental, bem como à falta de incentivos e de vontade política para garantir que o CDS disponha dos recursos necessários para um funcionamento eficaz, têm minado a potencialidade do órgão. Isto pode ser explicado justamente devido à diferença de percepções entre os Estados sul-americanos sobre o que deve ser priorizado nos termos da integração regional e, principalmente, que impacto tal integração pode gerar em suas respectivas políticas e estratégias de defesa. Além disso, a polissemia que define os diferentes entendimentos sobre questões de segurança e defesa na América do Sul marca o andamento das questões no âmbito do $\operatorname{CDS}$ e, ainda, reafirma as assimetrias existentes em outras áreas, como da economia (VAZ, FUCCILLE, REZENDE, 2017).

\section{CONSIDERAÇÕES FINAIS}

A análise do documento fundador do CDS demonstra que, na composição da agenda, há uma amplitude de temas que vão desde a soberania territorial e diminuição de assimetrias até a defesa dos recursos naturais. Neste sentido, o ineditismo do órgão reside no fato de este ser um arranjo de defesa composto apenas pelos países sul-americanos, algo que rompeu com a tradição de tutela estadunidense sobre as instituições regionais. Desta forma, o CDS significa a apropriação por parte da América do Sul de suas próprias questões de defesa, outrora pensadas sob a interferência de potências externas (LIMA, 2013; NERY, 2016). 
Concluímos que esta apropriação pode conduzir ainda à construção de uma identidade de defesa sul-americana; contudo, antes se faz necessário um debate sobre a convergência doutrinária entre os países membros, bem como sobre a adequação dos objetivos esperados com a cooperação em segurança e defesa. A concepção de instrumentos de cooperação regional deve passar pela reflexão crítica sobre as reais necessidades das unidades envolvidas, de maneira que seja possível identificar e perseguir objetivos comuns. No caso do CDS, a necessária construção de confiança entre os estados sul-americanos teve papel definidor em seus primeiros anos de atuação, quando se pôde acompanhar com nitidez a eficiência de sua estrutura e agenda em propor medidas que vieram a aproximar os estados. No entanto, o posterior descompasso em termos de agenda e objetivos comuns, somado a um contexto de esvaziamento da UNASUL, impôs travas ao aprofundamento da cooperação regional em segurança e defesa.

Destarte, nos seis anos iniciais de funcionamento do Conselho, foi possível observar evoluções positivas no que se refere ao surgimento de um espaço de concertação em temas de defesa, como as medidas de construção de confiança e o estabelecimento da CEED, algo que aproximou a região andina e o Cone Sul. Mas, passada a fase embrionária, a partir de 2014, com o início de uma nova onda política nos governos sul-americanos, o que se viu foi um enfraquecimento operacional no CDS. O resultado da mudança na balança de poder da região foi a diminuição da vontade política dos governos locais em continuar fornecendo incentivos para garantir o avanço das operações do Conselho.

Neste sentido, cabem muitos questionamentos sobre os próximos passos da regionalização da arquitetura de defesa sul-americana, após superada a dificuldade de conceber um órgão específico para pensar tais assuntos: questões sobre a existência ou não de uma corrida armamentista na região devido à reativação das indústrias de defesa, sobre as históricas problemáticas fronteiriças, ou, ainda, sobre como serão evitados os desequilíbrios políticos promovidos pelas assimetrias entre os Estados. Entretanto, é fato que a partir do CDS foi possível notar um posicionamento diferente por parte dos países, os quais compartilham valores sobre o que deve ser tratado no âmbito da segurança e da defesa. O conceito de "segurança multidimensional", por exemplo, não aparece nos documentos oficiais do 
Conselho, algo que denota um esforço no sentido de separar os assuntos de segurança pública da construção das políticas de defesa e, ainda, demonstra uma maturidade institucional.

\section{REFERÊNCIAS}

ABDUL-HAK, Ana Patrícia Neves. O Conselho de Defesa Sul-Americano: objetivos e interesses do Brasil. Brasília: FUNAG, 2013.

ARÁNGUIZ, Javiera Bayer. El Consejo de Defensa Suramericano y las nuevas amenazas. Revista Enfoques, v. 11, n. 19, p. 53-75, 2013.

ARRIGHI, Jean Michel. OEA: Organização dos Estados Americanos. São Paulo: Manole, 2004.

AYERBE, Luis Fernando. Estados Unidos e América Latina: a construção da hegemonia. São Paulo: UNESP, 2002.

BRASIL. MINISTÉRIO DA DEFESA. Política Nacional de Defesa e Estratégia Nacional de Defesa. Brasília, 2012.

BUZAN, Barry; WAEVER, Ole. Regions and Powers: The Structure of International Security. Cambridge: Cambridge University Press, 2003.

CABRAL, Ricardo. O Complexo Regional Sul-Americano: uma análise comparada. Tese de Doutorado, Programa de Pós-Graduação em História Comparada, Universidade Federal do Rio de Janeiro, 461 f., 2013.

CARDONA, Diego. El ABC de Unasur: doce preguntas y respuestas. Revista de la Integración, n. 2. Lima, 2008.

CARMO, Corival Alves. O projeto integracionista bolivariano de Hugo Chávez e o pragmatismo da política externa brasileira. In: SERBIN, Andrés; MARTíNEZ, Laneydi; RAMANZINI JR., Haroldo (coords.). El regionalismo "post-liberal” en América Latina y el Caribe: nuevos actores, nuevos temas, nuevos desafíos. Anuario de la Integración Regional de América Latina y el Gran Caribe. Buenos Aires: Coordinadora Regional de Investigaciones Económicas y Sociales, 2012.

CARVALHO, Glauber. A América do Sul em processo de transformação: desenvolvimento, autonomia e integração na Unasul. Dissertação de Mestrado, Programa de Pós-Graduação em Economia Política Internacional, Universidade Federal do Rio de Janeiro, 194 f., 2013.

CEPIK, Marco. Segurança na América do Sul: traços estruturais e dinâmica conjuntural.

Análise de Conjuntura OPSA, Rio de Janeiro, n. 9, p. 1-11, 2005. 
. Regional security and integration in South America: what UNASUR could learn from the OSCE and the Shanghai Cooperation Organization. In: KANET, Roger (ed.). The United States and Europe in a changing world. Republic of Letters, 2009.

DIAMINT, Rut. Regionalismo y posicionamiento suramericano: Unasur y ALBA. Revista CIDOB d'Afers Internacionals, n. 101, p. 55-79, 2013.

FAWCETT, Louise. The origins and development of the regional idea in the America. In: FAWCETT, Louise; SERRANO, Monica (eds.). Regionalism and Governance in the Americas. Continental Drift. New York: Palgrave Macmillan, p. 25-51, 2005.

FUCCILLE, Alexandre; REZENDE, Lucas. Complexo Regional de Segurança da América do Sul: uma nova perspectiva. Contexto Internacional, Rio de Janeiro, v. 35, n. 1, 2013.

FUCCILLE, Alexandre. O Brasil e a América do Sul: (re)pensando a segurança e defesa na região. Revista Brasileira de Estudos de Defesa, n. 1, p. 112-146, 2014.

. La construcción de un nuevo modelo de seguridad en América del Sur: una perspectiva desde Brasil. Anuario Latinoamericano - Ciencias Políticas y Relaciones Internacionales, v. 3, p. 169-182, 2016.

. Brasil e o Conselho de Defesa Sul-Americano (CDS): um balanço de uma década de sua existência. 11 Encontro da Associação Brasileira de Ciência Política, Curitiba, 2018.

HAAS, Ernst. The uniting of Europe. Indiana: University of Notre Dame Press, 2004.

HONÓRIO, Karen dos Santos. O significado da Iniciativa para a Integração da Infraestrutura Regional Sul-americana (IIRSA) no regionalismo sul-americano (2000-2012): um estudo sobre a iniciativa e a participação do Brasil. Dissertação de Mestrado, Programa De PósGraduação San Tiago Dantas, São Paulo, p. 70-85/ 90 -95, 2013.

KEOHANE, Robert. After Hegemony. Princeton: Princeton University Press, 1984. LIMA, Maria Regina Soares. Relações interamericanas: a nova agenda sul-americana e o Brasil. Lua Nova, n. 90, p. 16-201, 2013.

MALAMUD, Andrés. Regional integration in Latin America: comparative theories and institutions. Sociologia, Problemas e Práticas, n. 44, p. 135-154, 2004.

MARES, David. Violent Peace. Militarized interstate bargaining in Latin America. New York: Columbia University Press, 2001. 
MARIANO, Karina. Regionalismo na América do Sul: um novo esquema de análise e a experiência do Mercosul. São Paulo: Cultura Acadêmica, 2015.

MARTINS FILHO, João Roberto. Os Estados Unidos, a revolução cubana e a contra insurreição. Revista de Sociologia e Política, Curitiba, n. 12, 1999.

MERKE, Federico. Identidad y política exterior en Argentina y Brasil. Tese de Doutorado, Facultad Latinoamericana de Ciencias Sociales, Sede Académica Argentina, 2008.

MILNER, Helen. International theories of cooperation among nations: strengths and weaknesses. World Politics, n. 44, p. 466-496, 1992.

MONTEIRO, Licio. A União das Nações Sul-Americanas (Unasul) e o Conselho de Defesa SulAmericano (CDS): avanços e limites na construção da segurança regional da América do Sul. Anais do I Congresso Brasileiro de Geografia Política, Geopolítica e Gestão do Território. Rio de Janeiro: REBRAGEO, 2014.

NAFALSKI, Guilherme. Unasul: uma perspectiva política de integração sul-americana. Tese de Doutorado, Programa de Pós-Graduação em Sociologia, Universidade de São Paulo, São Paulo, 2010.

NERY, Tiago. Unasul: a dimensão política do novo regionalismo sul-americano. Caderno CRH, v. 29, n. 03, p. 59-75. Salvador, 2016.

OTÁLVORA, Edgar. Cooperación, integración o fusión militar en América del Sur. Policy paper, n. 14. Caracas: Friedrich Ebert Stiftung, 2007.

PÁDUA, Adriana; MATHIAS, Suzeley. Por una política de defensa común latinoamericana: la propuesta venezolana. Íconos: Revista de Ciencias Sociales, Quito, n. 38, p. 57-65, 2010.

PAGLIARI, Graciela de Conti. Segurança hemisférica: uma discussão sobre a validade e atualidade de seus mecanismos institucionais. Revista Brasileira de Política Internacional, v. 49, n. 1, p. 26-42, 2006.

PEDROSO, Carolina. Segurança na América do Sul: posições de Brasil e Venezuela no âmbito da Unasul. In: THOMAZ, Laís; MATHIAS, Suzeley; OLIVEIRA, Marcelo (orgs.). Diálogos SulAmericanos: 10 anos de política exterior. São Paulo: Cultura Acadêmica, 2015.

SAINT-PIERRE, Héctor Luis. La Defensa en la Política Exterior del Brasil: el Consejo Suramericano y la Estrategia Nacional de Defensa. Documento de Trabajo, n. 50. Madrid: Real Instituto Elcano, 2009. 
. "Defesa" ou "Segurança"? Reflexões em torno de conceitos e ideologias. Contexto

Internacional, v. 33, n. 2, p. 407-433, 2011.

SAINT-PIERRE, Héctor Luis; PALÁCIOS JUNIOR, Alberto Montoya. As medidas de confiança no Conselho de Defesa Sul-Americano (CDS): análise dos gastos em Defesa (2009-2012). Revista Brasileira de Política Internacional, v. 57, n. 1, p. 22-39, 2014.

SALTALAMACCHIA, Natalia. The rise of Latin American multilateralism: something old, something new. 55 ${ }^{\text {th }}$ Annual Convention of the International Studies Association, Toronto, 2014.

. Regional multilateralism in Latin America: Unasur, ALBA and CELAC. In:

DOMÍNGUEZ, Jorge; COVARRUBIAS, Ana (eds.). Routledge Handbook of Latin America in the World. New York: Routledge, 2015.

SANAHUJA, José Antonio. Regionalismo, cooperación y liderazgos en Sudamérica. El Consejo de Defensa de Unasur. Revista Atenea, n. 17, 2010.

. Regionalismo e integración en América Latina: de la fractura Atlántico Pacífico a los retos de una globalización en crisis. Pensamiento Propio, v. 21, p. 29-76, 2016.

SÁNCHEZ, Fabio. Unasur: poder y acción en Suramérica en el siglo XXI. Tese de Doutorado, Doctorado en Relaciones Internacionales e Integración Europea, Universitat Autònoma de Barcelona, 2015.

SARAIVA, Miriam Gomes. La política exterior brasileña hacia los países americanos en el proceso de integración: perspectivas de formulación y pragmatismo en práctica. Cuadernos sobre Relaciones Internacionales, Regionalismo y Desarrollo, v. 4. n. 8, p. 101-122, 2009.

Encontros e desencontros: o lugar da Argentina na política externa brasileira. Belo Horizonte: Fino Traço, 2012.

SOARES, Samuel Alves. Segurança e defesa no Cone Sul: transições com transformações? Estudos Ibero-Americanos, PUCRS, v. XXXIV, n. 1, p. 160-80, 2008.

SOLÓN, Pablo. Reflexiones a mano alzada sobre el Tratado de Unasur. Revista de la Integración, Lima, n. 2, 2008.

STELLA, Marco Dalla. L'UNASUR e l'integrazione regionale in America del Sud. Dissertação de Mestrado, Corso di Laurea Magistrale in Relazioni Internazionali Comparate, Università Ca'Foscari Venezia, Veneza, 154 f., 2012.

UNASUL. Tratado Constitutivo da União de Nações Sul-Americanas. Brasília, 2008. 
Decisión para el Establecimiento del Consejo de Defensa Suramericano de la UNASUR. Salvador, 2008b.

VAZ, Alcides; FUCCILLE, Alexandre; REZENDE, Lucas. Unasur, Brazil, and the South American defence cooperation: a decade later. Revista Brasileira de Política Internacional, v. 60, n. 2, e012, 2017.

VITELLI, Marina. The South American Defense Council: the building of a community of practice for regional defense. Revista Brasileira de Política Internacional, v. 60, n. 2, 2017.

XAVIER, Elaine de Melo. A UNASUL e a OEA na resolução de conflitos sul-americanos. Monografia, Especialização em Relações Internacionais, Universidade de Brasília, 63 f., 2010.

YOPO, Mladen. La seguridad regional: ¿'hacia una cooperación reforzada? Revista Política y Estratégica, n. 116, 2010.

ZURITA, Alejandro, El nacimiento tardío de la unificación sudamericana. La nueva orientación geopolítica, resaltando la aproximación de Brasil y Venezuela. História e Perspectivas, Uberlândia, n. 40, p. 269-291, 2009. 